\title{
The role of renal microvascular disease and interstitial inflammation in salt-sensitive hypertension
}

\author{
Bernardo Rodriguez-Iturbe ${ }^{1}$ and Richard J Johnson ${ }^{2}$
}

Primary (essential) hypertension has been shown to be mediated by a relative impairment in sodium excretion by the kidney, but the mechanisms responsible for this defect are still being clarified. Increasing evidence suggests a role for subtle acquired renal injury in mediating this process. Microvascular injury is present in the majority of subjects with hypertension. The development of arteriolosclerosis, primarily of the afferent arteriole, may interfere with glomerular autoregulation, whereas the loss of peritubular capillaries may facilitate local ischemia. These changes favor the localization of $\mathrm{T}$ cells and macrophages into the interstitium, which, coupled with local oxidative stress and angiotensin II generation, may contribute to the impaired pressure natriuresis observed with salt-sensitive hypertension. Consistent with this hypothesis, therapies that are aimed at blocking the immune response, including thymectomy, genetic alterations in mice resulting in impaired immune responses, or the use of immunosuppressive agents, can protect against the development of hypertension in experimental models. Preliminary data in humans also suggest that the inhibition of the renal inflammatory response may reduce blood pressure. The present investigations are directed to gain insight in the role of the intrarenal T-cell reactivity and autoimmunity in driving the tubulointerstitial inflammation and its participation in the pathogenesis of salt-sensitive hypertension.

Hypertension Research (2010) 33, 975-980; doi:10.1038/hr.2010.148; published online 5 August 2010

Keywords: interstitial inflammation; oxidative stress; pressure natriuresis; T cells

Hypertension (blood pressure $\geqslant 140 / 90 \mathrm{~mm} \mathrm{Hg}$ ) is present in nearly one billion people, affecting $25-43 \%$ of the world population older than 18 years, and is responsible for 7.1 million deaths and 64 million disease-adjusted life-years. ${ }^{1}$ Overwhelming evidence supports the relationship between dietary salt and blood pressure levels, ${ }^{2}$ and the importance of salt restriction is underlined by the WHO report indicating that two-thirds of the cerebrovascular accidents and half of the coronary artery events are related to hypertension. ${ }^{3}$ It has recently been estimated that a reduction of salt intake to $3 \mathrm{~g}$ per day would save 10-24 billions in health care annually in the United States 4 and reduction of the average sodium intake to $2300 \mathrm{mg}(100 \mathrm{mmol})$ per day would reduce the prevalence of hypertension by 11 million. ${ }^{5}$

The central role of the impairment in urinary sodium excretion in the pathogenesis of hypertension was hypothesized almost half a century ago by Borst and Borst-de Geuss, ${ }^{6}$ and the mechanisms relating the physiology of renal sodium excretion with the long-term control of blood pressure were presented by Guyton et al. ${ }^{7}$ Major support for this hypothesis was firmly established by the finding that hypertension 'travels with the kidney' in renal transplantation studies involving genetically hypertensive and normotensive rats, ${ }^{8-11}$ as well as in transplantation between normotensive donors and hypertensive patients. $^{12}$

Salt sensitivity, defined as abnormally pronounced variations of the blood pressure in response to sodium loading and sodium restriction, may be found in normotensive as well as hypertensive individuals, but is a feature present in $80 \%$ of hypertensive patients older than 60 years. ${ }^{13}$ Salt-sensitive hypertension (SSHTN) results from a variety of mechanisms that have in common the inability of the kidney to respond to salt loading with an appropriate increment in natriuresis (reviewed in Rodriguez-Iturbe et al. ${ }^{14}$ ). As postulated by Guyton, ${ }^{15}$ the increase in blood pressure is an adaptive response necessary to compensate for the impairment in pressure-natriuresis relationship. The present review is focused on the role of interstitial inflammation and renal microvascular disease in the development of an impaired natriuresis, which is the key renal defect driving SSHTN.

\section{RENAL MICROVASCULAR DISEASE AND INTERSTITIAL INFLAMMATION ARE FEATURES OF EXPERIMENTAL AND HUMAN HYPERTENSION}

Hypertension and microvascular disease

The association of renal arteriolar disease with hypertension has been recognized for a long time and fueled a debate on whether the 'arteriocapillary fibrosis' in the kidney was a cause or a consequence of hypertension. ${ }^{16}$ The controversy initially centered on the association of hypertension and vascular disease with 'chronic' Bright's disease, ${ }^{17-19}$ but it was soon recognized that hypertension could be present without renal parenchymal damage. An important autopsy study, published in the 1930s, reported that arteriolar disease

${ }^{1}$ Hospital Universitario and Universidad del Zulia, IVIC-Zulia, Maracaibo, Venezuela and ${ }^{2}$ Division of Renal Diseases and Hypertension, University of Colorado, Denver, CO, USA Correspondence: Professor B Rodriguez-Iturbe, Servicio de Nefrología, Hospital Universitario de Maracaibo, Avenida Goajira s/n, Maracaibo, Estado Zulia 4001-A, Venezuela. E-mail: bernardori@telcel.net.ve

Received 28 April 2010; revised 11 June 2010; accepted 27 June 2010; published online 5 August 2010 
('arteriolosclerosis') was much more likely to be present in the kidneys of hypertensive subjects than in other organs such as the spleen. ${ }^{20}$ This led Goldblatt to hypothesize that the renal arteriolar disease might have a primary role in causing hypertension, which he postulated was by causing renal ischemia. ${ }^{21}$ Studies by several investigators ${ }^{22-24}$ evidenced renal microvascular changes in hypertension, but the experiments of Goldblatt induced renal ischemia by clamping of the renal artery ${ }^{25}$ and the arteriolar changes in the human appear secondary to hypertension because they were more severe in subjects whose blood pressure was higher or greater in duration. ${ }^{26}$ Furthermore, in 1948, Castelman and Smithwick ${ }^{24}$ evaluated renal biopsy specimens of patients with essential hypertension obtained during sympathectomy operations that were at the time performed as a treatment for high blood pressure and found that $10-20 \%$ had only mild renal microvascular disease. These data led to a general abandonment of the Goldblatt hypothesis, and renal arteriolosclerosis has generally been considered as a structural consequence to persistent elevated blood pressure.

Additional evidence against the renal arteriolosclerosis hypothesis was published in the mid-1950s. A key study was performed by Sommers et al.,27 who evaluated 1766 renal biopsy specimens of 1350 patients with different stages of hypertension, including some of the same patients from the earlier study by Castelman and Smithwick. ${ }^{24}$ In this detailed study, some degree of arteriolar thickening was present in over $98 \%$ of the biopsy specimens, with evidence for renal ischemia in $99 \%$ of cases. Although the blood pressure of these patients and the duration of disease were not mentioned, in a separate report of these patients ${ }^{28}$ it was indicated that the severity of arteriolar changes was associated with the severity of hypertension and with the age of the patient. Patients with normal renal arterioles had a mean preoperative diastolic blood pressure of $100 \mathrm{mmHg}$. Therefore, although renal arteriolosclerosis was indeed a feature of severe hypertension, it was not present in the few cases with milder elevation of blood pressure and the authors concluded that hypertension precedes the changes in renal vasculature. ${ }^{27}$

Although these studies argued that arteriolosclerosis was not the cause of hypertension, the presence of these changes was thought to be a key element in causing chronic ischemia within the kidney and thereby triggering and accentuating glomerular sclerosis and postglomerular ischemia, oxidative stress, upregulation of vasoconstricting mediators and tubulointerstitial damage. ${ }^{29}$ Therefore, the development and the severity of lesions in the medium and small renal arteries could be a mechanism for inducing renal injury, reducing GFR and causing renal vasoconstriction, which could have a role in reducing filtered sodium and impairing pressure natriuresis in SSHTN.

In 1997, Johnson and Schreiner ${ }^{30}$ called attention to the role of the integrity of the peritubular capillaries in the pressure natriuresis mechanism and suggested a role for loss and rarefaction of interstitial capillaries resulting from acquired tubulointerstitial injury. According to this hypothesis, episodic increments in blood pressure could result in transient increased pressure, especially in the outer medullary region of the kidney, where it might induce endothelial cell injury. The peritubular capillaries consist of only endothelial cells and the basement membrane, and are devoid of the protection afforded by smooth muscle and pericytes. The deleterious effects of increased pressure on the postglomerular capillary network are reinforced by local vasoconstriction and oxidative stress associated with increased angiotensin or catecholamine activity, which are known to reduce interstitial blood flow of the vasa rectae. ${ }^{31}$ In fact, both norepinephrine and angiotensin are known to increase peritubular capillary pressure. ${ }^{32}$ Eventually, peritubular capillaries are permanently damaged and reduced in number, thus causing ischemia, increasing the oxidative stress, and mediating tubulointerstitial inflammation and impairment of pressure diuresis. In support of this hypothesis, a reduction in peritubular capillary density was demonstrated in experimental models of SSHTN ${ }^{33-35}$ and in humans with essential hypertension. ${ }^{36}$

\section{Hypertension and tubulointerstitial inflammation}

Although not emphasized in the 1958 classical study of Sommers et al., ${ }^{27}$ inflammatory infiltration was a constant feature in the renal biopsies of hypertensive patients and, more importantly, the authors did note 'collections of lymphocytes' in the renal interstitium in about $20 \%$ of the hypertensive patients that had minimal or no arteriolar changes. The relevance of this finding in the pathogenesis of hypertension is now becoming more evident. First, accumulation of immune-competent cells such as lymphocytes and macrophages in tubulointerstitial areas of the kidney is a universal finding in experimental models of hypertension. Second, and more significantly, the inhibition of the interstitial infiltrates with immunosuppressive agents either prevents or ameliorates the development of hypertension (reviewed in Rodriguez-Iturbe et al. ${ }^{14}$ ).

The importance of the immune system in hypertension was first suggested by studies performed by Svendsen more than 30-years ago. ${ }^{37}$ Specifically, Svendsen found that the salt-dependent phase of DOCAsalt hypertension did not develop in athymic 'nude' mice. However, if the thymus gland was transplanted into these athymic mice, then the capacity for developing salt-driven hypertension was restored. Svendsen then showed that the thymus was also necessary for the chronic phase of the hypertension that follows partial renal infarction. ${ }^{38}$ Subsequently, Norman and co-workers, ${ }^{39}$ working in the same model, reported that the immunosuppressive agent, cyclophosphamide, also had antihypertensive effects. Anti-thymocyte serum has also been reported to transiently reduce the blood pressure in spontaneously hypertensive rats. ${ }^{40}$ Additional studies suggested that hypertension in this model was associated with altered immune reactivity, as evidence by impaired blastogenic responses and altered cellular immune reactivity. ${ }^{41}$

Our group has hypothesized that the benefit of immunosuppression on salt sensitivity may relate in part to a direct inhibition of the inflammatory response that occurs in the kidneys in SSHTN. Indeed, we have noted a remarkable relationship between the presence of $\mathrm{T}$ cells and macrophages in the interstitium with salt-sensitive blood pressure in numerous models. ${ }^{42-44}$ More importantly, we also found that the reduction of the renal inflammatory response by mycophenolate mofetil could prevent the salt-dependent hypertension that occurs following subcutaneous angiotensin infusion, ${ }^{42}$ following the temporary inhibition of nitric oxide synthase $e^{43}$ and the hypertension that occurs with protein overload nephropathy. ${ }^{44}$ Subsequently, a large number of studies from several laboratories, including our own, found that treatments directed to suppress renal inflammation are associated with prevention or amelioration of hypertension. Table 1 summarizes the studies that have demonstrated that immune suppression prevents or ameliorates hypertension..$^{37-40,42-62}$ Of interest, these models include experimentally induced (acquired models) SSHTN, prenatally programmed hypertension and genetic models of hypertension. Treatments used include means that can block intrarenal lymphocyte localization or function, lymphocyte depletion strategies, inhibition of $\mathrm{NF}-\kappa \mathrm{B}$ activation and several categories of immunosuppressive drugs.

Recent clinical studies also suggest an association between renal inflammation and essential hypertension. Patients with grade I hypertension and normal renal function who received mycophenolate mofetil for the treatment of psoriasis or rheumatoid arthritis had a 
Table 1 Studies associating immune depletion with amelioration or prevention of hypertension

\begin{tabular}{|c|c|c|}
\hline Treatment/condition & Experimental model & Reference \\
\hline \multicolumn{3}{|l|}{ Lymphocyte depletion } \\
\hline Nude mice & DOCA-salt hypertension & 37 \\
\hline \multirow[t]{3}{*}{ Neonatal thymectomy } & Renal infarction (chronic phase) & 38 \\
\hline & Lyon hypertensive rats & 45 \\
\hline & Hypertensive NZB mice & 46 \\
\hline Rag-/- mice & Angiotensin II-induced hypertension & 47 \\
\hline Anti-lymphocyte serum & SHR & 40 \\
\hline \multicolumn{3}{|l|}{ Cytokine depletion } \\
\hline Interleukin-6 knockout mice & Angiotensin II-induced hypertension & 48 \\
\hline \multicolumn{3}{|c|}{ Inhibition of proinflammatory transcription factors } \\
\hline \multirow[t]{2}{*}{ Inhibition of NF-кB } & SHR & 49 \\
\hline & dTGF rats & 50 \\
\hline \multicolumn{3}{|l|}{ Immunosuppressive treatment } \\
\hline \multirow[t]{9}{*}{ Mycophenolate mofetil } & SHR & 51 \\
\hline & Dahl-salt sensitive & 52,53 \\
\hline & All infusion & 42 \\
\hline & NOS inhibition & 43 \\
\hline & Chronic lead toxicity & 55 \\
\hline & Overload proteinuria & 44 \\
\hline & Cellophane-wrapped kidney & 55 \\
\hline & Prenatally programmed hypertension & 56 \\
\hline & Grade I hypertension (humans) & 57 \\
\hline Cyclosporin A & dTGF rats & 58 \\
\hline \multirow[t]{3}{*}{ Cyclophosphamide } & SHR & 59 \\
\hline & Black New Zealand mice & 46 \\
\hline & Renal infarction (chronic phase) & 39 \\
\hline \multicolumn{3}{|c|}{$\begin{array}{l}\text { Reduction of oxidative stress (studies specifically looking for reduction in } \\
\text { inflammation associated with lowering of } B P \text { ) }\end{array}$} \\
\hline \multirow[t]{2}{*}{ Antioxidant diets } & SHR & 60 \\
\hline & Mineralocorticoid hypertension & 61 \\
\hline Melatonin & SHR & 62 \\
\hline
\end{tabular}

Abbreviations: BP, blood pressure; SHR, spontaneously hypertensive rat.

significant reduction in blood pressure concomitant with a reduction in urinary excretion of inflammatory cytokines. ${ }^{57}$ Hughson et al. ${ }^{63}$ also examined renal autopsies of hypertensive and normotensive White and African-American subjects, and their data show that macrophage infiltration is more intense in hypertensive individuals and that the intensity of the macrophage accumulation was strongly correlated with the severity of hypertension.

In these studies there are both $\mathrm{T}$ cells and macrophages present in the interstitium. Most of the immunosuppressive therapies will reduce both populations, and hence it is unclear if both cell types are required or if there is a role for either the $\mathrm{T}$ cell or the macrophage. However, a key role for the $\mathrm{T}$ cell in experimental hypertension has recently been reported by Guzik et al., ${ }^{47}$ who showed that Rag-/- mice without lymphocytes were resistant to the hypertensive effects of angiotensin II and the adoptive transfer of $\mathrm{T}$ cells from the wild-type mice conferred a normal hypertensive response.

Recent work by Titze and co-workers ${ }^{64}$ have uncovered a new system that permits buffering the effects of salt intake on the blood pressure. Sodium is bound to proteoglycans in the interstitial space under the skin, where the local hypertonicity drives an increase of the lymphatics as a consequence of the production of vascular endothelial growth factor- $\mathrm{C}$ by the macrophages activated by the tonicity-responsive enhancer binding protein. The 'third' space thus formed by the hyperplasia of the lymphatic network serves to ameliorate the increment in blood pressure that would otherwise result from a high-salt diet.

\section{IMPAIRMENT IN SALT EXCRETION AS A CONSEQUENCE OF RENAL MICROVASCULAR DISEASE AND TUBULOINTERSTITIAL INFLAMMATION}

Impairment in the pressure natriuresis is an expected consequence of reduced peritubular capillary network and accumulation of lymphocytes and macrophages in tubulointerstitial areas of the kidney. Reduced microvascular surface, increased interstitial space and eventual development of fibrosis reduce and separate the surface areas of sodium transfer and impair diffusion capacity in the interstitial space.

In addition to these physical effects, tubulointerstitial inflammation drives a tendency to sodium retention resulting from a combination of reduction in filtered sodium in the glomeruli and stimulation of sodium reabsorption in tubular areas. These effects depend on the constant association of inflammation, angiotensin II and oxidative stress in tubulointerstitial areas of the kidney. ${ }^{65}$ The reduced filtration of sodium would result not only as a consequence of the vasoconstriction caused by angiotensin II in the glomerular circulation but also as a result of angiotensin II-induced upregulation of the tubuloglomerular feedback mechanism. ${ }^{30}$ As angiotensin II is also one of the most potent humoral factors that stimulate proximal tubular sodium reabsorption, ${ }^{66}$ the net result of increased angiotensin II activity is a strong tendency to sodium retention. Interstitial inflammation and angiotensin activity are also inevitably associated with oxidative stress that, in itself, is a significant influence that impairs sodium excretion. The role of oxidative stress in the renal medulla driving sodium retention has been extensively investigated by Cowley et al. ${ }^{67,68}$ Impaired pressure natriuresis and stimulated tubuloglomerular feedback have also been demonstrated in patients with hypertension. ${ }^{69}$

The long-term effects of tubulointerstitial inflammation may also have a role in the progression of chronic renal disease. Tubulointerstitial inflammation is associated with proliferative changes that result in rearrangement of extracellular matrix proteins in the vascular smooth muscle and reduction in its response to contractile stimuli. ${ }^{70}$ Tubulointerstitial inflammation in salt-sensitive hypertensive models is also associated with phenotypic alterations in afferent arteriolar morphology, which appears to alter the normal autoregulatory response involved in glomerular hemodynamics. ${ }^{71}$ A consequence of the afferent arteriolar disease is glomerular hypertension, which is known to have a hemodynamic role in renal disease progression. ${ }^{69}$ Local cytokines and growth factors may contribute to these changes, as noted by the dose-dependent impairment of protective afferent vasoconstriction induced by transforming growth factor- $\beta{ }^{72}$ Progressive nephron loss, with diminished capacity for sodium excretion, is the consequence of the loss of these important autoregulatory processes. ${ }^{73}$

\section{IMMUNE REACTIVITY AND HYPERTENSION}

Although there is mounting evidence supporting the contention that tubulointerstitial inflammation and reduction in the peritubular capillary network are a final common pathway in the development of salt-driven hypertension (reviewed in Rodriguez-Iturbe et al. ${ }^{14}$ and Johnson et al. ${ }^{29}$ ), scarce information exists on the mechanisms 

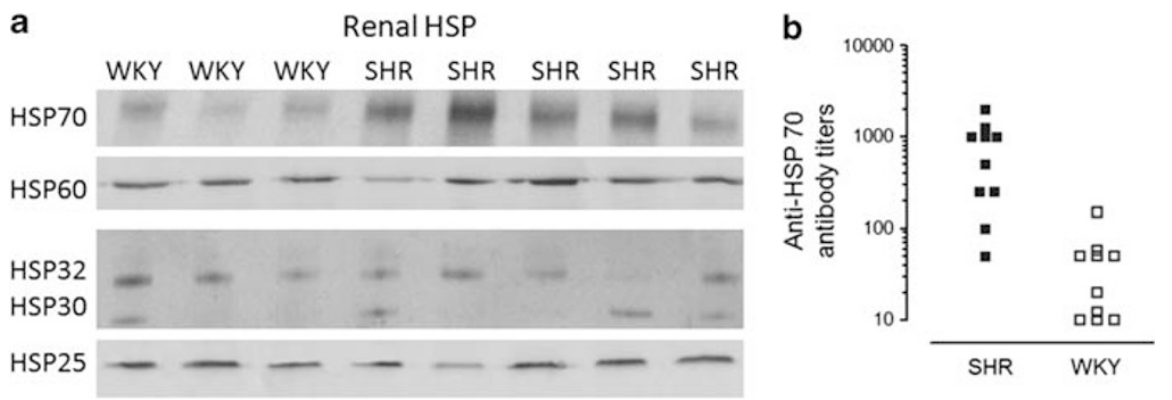

Figure 1 (a) Renal abundance (western blot) of heat shock proteins (HSPs) in Wistar Kyoto rats (WKY) and spontaneously hypertensive rats (SHR). Only levels of HSP70 were consistently increased in SHR. (b) Plasma anti-HSP70 antibody titers (enzyme-linked immunoassay) in 30-week-old SHR (closed squares) and control WKY (open squares). Data obtained in 30-week-old SHR (systolic blood pressure $181.5 \pm \mathrm{SD} 21.6 \mathrm{mmHg}$ ) and WKY $(125.8 \pm 9.53 \mathrm{~mm} \mathrm{Hg})$ control rats. Data presented in part in the 2007 World Congress of Nephrology. ${ }^{87}$

of development and long-term maintenance of the inflammatory reactivity. We have raised the possibility that autoimmune reactivity could be responsible for the low-grade tubulointerstitial inflammation in the kidney that, in concert with local angiotensin II generation and oxidative stress, would provide the critical intrarenal milieu that would favor the chronic impairment in pressure natriuresis that underlies SSHTN. ${ }^{74}$

Previous studies that examined the immune reactivity in hypertension have given conflicting results. In contrast with the experimental data that indicate that suppression of the immune system ameliorated hypertension, Tuttle and Boppana ${ }^{75}$ reported that interleukin 2 had antihypertensive effects and it was suggested that activation of the immune system could be an adaptive response directed to suppress what otherwise could be life-threatening increments in blood pressure. ${ }^{40}$ Kristensen and Andersen ${ }^{76}$ reported that hypertensive patients have increased levels of serum autoantibodies and delayed-type hypersensitivity reactions against vascular antigens. Investigations on the relationship between immune reactivity and hypertension were then largely abandoned. In 1990, Dzielak ${ }^{77}$ commented that 'immune dysfunction is rarely mentioned in discussions on arterial hypertension' and suggested that this omission should be reconsidered in view of the 'body of evidence that implicates altered immunological function in the development of some forms of hypertension.'

Recently we have focused on heat shock proteins (HSPs) as selfantigens that might trigger and sustain interstitial inflammation in SSHTN. HSP70 is localized in the major histocompatibility complex, but no evidence of linkage between the HSP70 gene locus and blood pressure has been demonstrated. ${ }^{78}$ However, Hamet et al. ${ }^{79}$ have shown that HSP70 mRNA is increased in hypertensive rats and HSPs are known to be able to induce autoimmune reactivity, ${ }^{80,81}$ and Ishizaka et al., ${ }^{82}$ as well as our group, ${ }^{83}$ have documented the overexpression of HSP70 in the kidney in models of salt-sensitive hypertension. Spontaneously hypertensive rats that are 30 weeks old present increased renal abundance of HSP70 (but not HSP60, HSP32 and HSP25) and plasma anti-HSP70 antibodies (Figure 1), and increased serum antibody levels to HSP70 and HSP65 have also been reported in patients with hypertension. ${ }^{84}$ HSP70 levels have also been found to predict the development of atherosclerosis. ${ }^{85}$ Furthermore, experimental induction of SSHTN is associated with a proliferative response of splenocytes to HSP70. ${ }^{86}$ These studies raise the interesting possibility that autoimmune reactivity involving selfantigens such as HSP70 may have a role in the pathogenesis of hypertension.
1 Staessen JA, Wang J, Bianchi G, Birkenhäger WH. Essential hypertension. Lancet 2003; 361: 1629-1641.

2 He FJ, Macgregor GA. A comprehensive review on salt and health and current experience of worldwide salt reduction programmes. J Hum Hypertens 2008; 23: 363-384.

3 WHO. The World Health Report 2002. Reducing risks, promoting healthy life. 2002. http://www.who.int/whr/2002/en/.

4 Bibbins-Domingo K, Chertow GM, Coxson PG, Moran A, Lightwood JM, Pletcher MJ, Goldman L. Projected effect of dietary salt reductions on future cardiovascular disease. N Engl J Med 2010; 362: 590-599.

5 Palar K, Sturm R. Potential societal savings from reduced sodium consumption in the US adult population. Am J Health Promot 2009; 24: 49-57.

6 Borst JGG, Borst-de Geuss A. Hypertension explained by Starling's theory of circulatory homoeostasis. Lancet 1963; 1: 677-682.

7 Guyton AC, Coleman TG, Cowley Jr AW, Scheel KW, Manning Jr RD, Norman Jr RA. Arterial pressure regulation: overriding dominance of the kidneys in long-term regulation and in hypertension. Am J Med 1972; 52: 584-594.

8 Dahl LK, Heine M, Thompson K. Genetic influence of renal homografts on the blood pressure of rats from different strains. Proc Soc Exp Biol Med 1972; 140: 852-856.

9 Bianchi G, Fox U, Di Francesco gF, Bardi U, Radice M. The hypertensive role of the kidney in spontaneously hypertensive rats. Clin Sci Mol Med 1973; 45(Suppl 1): 135S-139s.

10 Heller J, Schubert G, Havlickova J, Thurau K. The role of the kidney in the development of hypertension: a transplantation study in the Prague hypertensive rat. Pflügers Arch 1993; 425: 208-212.

11 Morgan DA, DiBona GF, Mark AL. Effects of interstrain renal transplantation on $\mathrm{NaCl}-$ induced hypertension in Dahl rats. Hypertension 1990; 15: 436-442.

12 Curtis JJ, Luke RG, Dustan HP, Kashgarian M, Whelchel JD, Jones P, Diethelm AG. Remission of essential hypertension after renal transplantation. N Engl J Med 1983; 309: 1009-1015.

13 Weinberg M, Fineberg N. Sodium and volume sensitivity of blood pressure. Age and pressure change over time. Hypertension 1991; 18: 67-71.

14 Rodriguez-Iturbe B, Romero F, Johnson RJ. Pathophysiologic mechanisms of saltdependent hypertension. Am J Kidney Dis 2007; 50: 655-672.

15 Guyton AC. Blood pressure control: special role of the kidneys and body fluids. Science 1991; 252: 1813-1816.

16 Gull W, Sutton H. On the pathology of the morbid state commonly called chronic Brights disease with contracted kidney 'arterio-capillary fibrosis'. Med Chir Trans 1872; 55: 325-371.

17 Johnson G. The anatomy of Bright's disease: the arterio-capillary fibrosis of Sir William Gull and Dr. Sutton. Br Med J 1972; 1: 604-605.

18 Folkow B. Structure and function of the arteries in hypertension. Am Heart J 1987; 114: 938-948.

19 Mahomed FA. The etiology of Bright's disease and the prealbuminuric state. Med Chir Trans 1874; 39: 197-228.

20 Moritz A, Oldt M. Arteriolar sclerosis in hypertensive and non-hypertensive individuals. Am J Pathol 1937; 13: 679-728.

21 Goldblatt H. The renal origin of hypertension. Physiol Rev 1947; 27: 120-165.

22 Kimmelstiel P, Wilson C. Benign and malignant hypertension and nephrosclerosis. A clinical and pathological study. Am J Pathol 1936; 12: 45-81.

23 Wilson C. Renal factors in the production of hypertension. Lancet 1953; 1: 579-584, 632-638.

24 Castelman B, Smithwick $\mathrm{RH}$. The relation of vascular disease to the hypertensive state. Based on a study of renal biopsies from one hundred hypertensive patients. J Am Med Assoc 1943; 121: 1256-1261.

25 Goldblatt H, Lynch J, Hanzal R, Summerville W. Studies on experimental hypertension. I. The production of persistent elevation of systolic blood pressure by means of renal ischemia. J Exp Med 1934; 59: 347-379. 
26 Perera GA. Hypertensive vascular disease; description and natural history. J Chronic Dis 1955; 1: 33-42.

27 Sommers SC, Relman AS, Smithwick RH. Histologic studies of kidney biopsy specimens from patients with hypertension. Am J Pathol 1958; 34: 685-715.

28 Saltz M, Sommers SC, Smithwick RH. Clinicopathologic correlations of renal biopsies from essential hypertensive patients. Circulation 1957; 16: 207-212.

29 Johnson RJ, Herrera J, Schreiner G, Rodríguez-Iturbe B. Acquired and subtle renal injury as a mechanism for salt-sensitive hypertension: bridging the hypothesis of Goldblatt and Guyton. N Engl J Med 2007; 346: 913-923.

30 Johnson RJ, Schreiner G. Hypothesis: the role of acquired tubulointerstitial disease in the pathogenesis of salt-dependent hypertension. Kidney Int 1997; 52: 1169-1179.

31 Faubert PF, Chou SY, Porush JG. Regulation of papillary plasma flow by angiotensin II. Kidney Int 1987; 32: 472-478.

32 Myers BD, Deen WM, Brenner BM. Effects of norepinephrine and angiotensin II on the determinants of glomerular ultrafiltration and proximal tubule reabsorption in the rat. Circ Res 1975; 37: 101-110.

33 Johnson RJ, Gordon KL, Suga S, Duijvestijn AM, Griffin K, Bidani A. Renal injury and salt-sensitive hypertension after exposure to catecholamines. Hypertension 1999; 34: 151-159.

34 Andoh TF, Johnson RJ, Lam T, Bennet WM. Subclinical renal injury induced by cyclosporine exposure is associated with salt-sensitive hypertension. Am J Transplant 2001; 1: 222-227.

35 Raqy PE, Suga S, Lin X-H, Huang X, Johnson RJ. Chronic potassium depletion induces renal injury, salt-sensitivity and hypertension in young rats. Kidney Int 2001; 59: 1850-1858.

36 Bohle A, Muller G, Whermann M, Mackensen-Haen S, Xiao J-C. Pathogenesis of chronic renal failure in the primary glomerulopathies, renal vasculopathies and chronic interstitial nephritides. Kidney Int 1996; 49(Suppl 54): S2-S9.

37 Svendsen UG. Evidence for an initial, thymus independent and a chronic, thymusdependent phase of DOCA and salt hypertension in mice. Acta Path Microbiol Scand A 1976; 84: 523-528.

38 Svendsen UG. The importance of thymus in the pathogenesis of the chronic phase of hypertension in mice following partial infarction of the kidney. Acta Pathol Microbiol Scand A 1977; 85: 539-547.

39 Norman Jr RA, Galloway PG, Dzielak DJ, Huang M. Mechanisms of partial renal infarct hypertension. J Hypertens 1988; 6: 397-403.

40 Bendich A, Belisle EH, Strausser HR. Immune system modulation and its effects on blood pressure of the spontaneously hypertensive male and female rat. Biochem Biophys Res Commun 1981; 99: 600-607.

41 Takeichi N, Suzuli F, Kobayashi H. Immunologic depression in spontaneously hypertensive rats. Clin Exp Immunol 1980; 40: 120-126.

42 Rodríguez-Iturbe B, Pons H, Quiroz Y, Gordon K, Rincón J, Chávez M, Parra G, HerreraAcosta J, Gómez-Garre D, Largo R, Egido J, Johnson RJ. Mycophenolate mofetil prevents salt-sensitive hypertension resulting from angiotensin II exposure. Kidney Int 2001; 59: 2222-2232.

43 Quiroz Y, Pons H, Gordon KL, Rincón J, Chávez M, Parra G, Herrera-Acosta J, GómezGarre D, Largo R, Egido J, Johnson RJ, Rodríguez-Iturbe B. Mycophenolate mofetil prevents the salt-sensitive hypertension resulting from short-term nitric oxide synthesis inhibition. Am J Physiol Renal Physiol 2001; 281: F38-F47.

44 Alvarez V, Quiroz Y, Nava M, Pons H, Rodríguez-Iturbe B. Overload proteinuria is followed by salt-sensitive hypertension caused by renal infiltration of immune cells. Am J Physiol Renal Physiol 2002; 283: F1132-F1141.

45 Bataillard P, Freiche J-C, Vincent M, Touraine J-L, Sassard JU. Effects of neonatal thymectomy on blood pressure and immunological characteristics of the genetically hypertensive rats of the Lyon strain. J Hypertens 1986; 4(Suppl 3): 5455-5467.

46 Svendsen UG. Spontaneous hypertension and hypertensive vascular disease in the NZB strain of mice. Acta Pathol Microbiol Scand A 1977; 85: 548-554.

47 Guzik TJ, Hoch NE, Brown KA, McCann LA, Rahman A, Dikalov S, Goronzy J, Weyand $C$, Harrison DG. Role of the T cell in the genesis of angiotensin II induced hypertension and vascular dysfunction. J Exp Med 2007; 204: 2449-2460.

48 Lee DL, Sturgis LC, Labazi H, Osborne Jr JB, Fleming C, Pollock JS, Manhiani M, Imig JD, Brands MW. Angiotensin II hypertension in attenuated in interleukin-g knockout mice. Am J Physiol Heart Circ Physiol 2006; 290: H935-H940.

49 Rodríguez-Iturbe B, Ferrebuz A, Vanegas V, Quiroz Y, Mezzano S, Vaziri ND. Early and sustained inhibition of nuclear factor kappa B prevents hypertension in spontaneously hypertensive rats. J Pharmacol Exp Ther 2005; 315: 51-57.

50 Müller DN, Dechend R, Mervaal EMA, Park J-K, Schmidt F, Fiebler A, Theuer J, Breu V, Ganten D, Haller H, Luft FC. NF-kB inhibition ameliorates angiotensin II-induced inflammatory damage in rats. Hypertension 2000; 35(Part 2): 193-201.

51 Rodríguez-Iturbe B, Quiroz Y, Nava M, Bonet L, Chávez M, Herrera-Acosta J, Johnson RJ, Pons HA. Reduction of renal immune cell infiltration results in blood pressure control in genetically hypertensive rats. Am J Physiol Renal Physiol 2002; 282: F191-F201.

52 Mattson DL, James L, Berdan EA, Meister CJ. Immune suppression attenuates hypertension and renal disease in Dahl salt-hypertensive rats. Hypertension 2006; 48: 149-156.

53 Tian N, Gu JW, Braddy SJ, Rose RA, Hughson MD, Manning Jr RD. Immune suppression prevents renal damage and dysfunction and reduces arterial pressure in salt-sensitive hypertension. Am J Physiol Heart Circ Physiol 2007; 292 H1018-H1025.

54 Bravo Y, Quiroz Y, Ferrebuz A, Vaziri ND, Rodríguez-Iturbe B. Mycophenolate mofetil administration reduces renal inflammation, oxidative stress and arterial pressure in rats with lead-induced hypertension. Am J Physiol Renal Physiol 2007; 297: F616-F623.

55 Vanegas V, Ferrebuz A, Quiroz Y, Rodríguez-Iturbe B. Hypertension in Page (cellophane wrapped) kidney is due to interstitial nephritis. Kidney Int 2005; 68: 1161-1170.

56 Stewart T, Jung FF, Manning J, Vehaskari VM. Kidney immune cell infiltration and oxidative stress contribute to prenatally programmed hypertension. Kidney Int 2005; 68: 2180-2188.

57 Herrera J, Ferrebuz A, MacGregor EG, Rodríguez-Iturbe B. Mycophenolate mofetil treatment improves hypertension in patients with psoriasis and rheumatoid arthritis. J Am Soc Nephrol 2006; 17(Suppl 3): S218-S225.

58 Mervaala E, Müller DN, Park J-K, Dechend R, Schmidt F, Fiebler A, Bieringer M, Breu V, Ganten D, Haller H, Luft FC. Cyclosporin A protects against Angiotensin II-induced endorgan damage in double transgenic rats harboring human renin and angiotensiogen genes. Hypertension 2000; 35: 360-366.

59 Khraibi AA, Norman Jr RA, Dzielak DJ. Chronic immunosuppression attenuates hypertension in Okamoto spontaneously hypertensive rats. Am J Physiol 1984; 247(Heart Circ Physiol 16): H722-H726.

60 Rodríguez-Iturbe B, Zhan CD, Quiroz Y, Sindhu RK, Vaziri ND. Antioxidant-rich diet improves hypertension and reduces renal immune infiltration in spontaneously hypertensive rats. Hypertension 2003; 41: 341-346.

61 Beswick RA, Zhang H, Marable D, Catravas JD, Hill WD, Webb RC. Long-term antioxidant administration attenuates mineralocorticoid hypertension and renal inflammatory response. Hypertension 2001; 37: 781-786.

62 Nava M, Quiroz Y, Vaziri ND, Rodríguez-Iturbe B. Melatonin reduces renal interstitial inflammation and improves hypertension in spontaneously hypertensive rats. $A m \mathrm{~J}$ Physiol Renal Physiol 2003; 284: F447-F454.

63 Hughson MD, Gobe GC, Hoy WE, Manning Jr RD, Douglas-Denton R, Bertram JF. Associations of glomerular number and birth weight with clinicopathological features of African Americans and whites. Am J Kidney Dis 2008; 52: 18-28.

64 Machnik A, DahImann A, Kopp C, Goss J, Wagner H, van Rooijen N, Eckardt KU, Müller DN, Park JK, Luft FC, Kerjaschki D, Titze J. Mononuclear phagocyte system depletion blocks interstitial tonicity-responsive enhancer binding protein/vascular endothelial growth factor $\mathrm{C}$ expression and induces salt-sensitive hypertension in rats. Hypertension 2010; 55: 755-761.

65 Vaziri ND, Rodriguez-Iturbe B. Mechanisms of disease: oxidative stress and inflammation in the pathogenesis of hypertension. Nat Clin Pract Nephrol 2006; 2: 582-593.

66 Navar LG, Harrison-Bernard LM, Nishiyama A, Kobori H. Regulation of intrarenal angiotensin II in hypertension. Hypertension 2002; 39: 316-322.

67 Cowley AW. Renal medullary oxidative stress, pressure-natriuresis and hypertension. Hypertension 2008; 52: 777-786.

68 Makino A, Skelton MM, Zou AP, Roman RJ, Cowley Jr AW. Increased renal medullary oxidative stress produces hypertension. Hypertension 2002; 39: 667-672.

69 Kurokawa K. Kidney, salt and hypertension: how and why. Kidney Int 1996; 49(Suppl 55): S46-S51.

70 Touyz RM, He G, El Mabroul M, Schiffrin EL. p38 MAP kinase regulates vascular smooth muscle cell collagen synthesis by angiotensin II in SHR but not in WKY. Hypertension 2001; 37: 574-580.

71 Sánchez-Lozada LG, Tapia E, Johnson RJ, Rodríguez-Iturbe B, Herrera-Acosta J. Glomerular hemodynamic changes associated with arteriolar lesions and tubulointerstitial inflammation. Kidney Int 2003; 64(Suppl 86): S9-S14.

72 Sharma K, Cook A, Smith M, Valancius C, Inscho EW. TGF-beta impairs renal autoregulation via generation of ROS. Am J Physiol Renal Physiol 2005; 288: F1069-F1077

73 Bidani AK, Griffin KA. Pathophysiology of hypertensive renal damage. Implications for therapy. Hypertension 2004; 44: 595-601.

74 Rodriguez-Iturbe B, Vaziri ND, Herrera-Acosta J, Johnson RJ. Oxidative stress, renal infiltration of immune cells and salt-sensitive hypertension: all for one and one for all. Am J Physiol Renal Physiol 2004; 286: F606-F616.

75 Tuttle RS, Boppana DP. Antihypertensive effect of interleukin 2. Hypertension 1990; 15: 89-94.

76 Kristensen BO, Andersen PL. Autoantibodies in untreated and treated essential hypertension. Acta Med Scand 1978; 203: 55-59.

77 Dzielak DJ. AIDS, lupus, rheumatoid arthritis-hypertension? Hypertension 1990; 15 : 95-96.

78 Lodwick D, Kaiser MA, Harris J, Privat P, Vincent M, Sassard J, Samani NJ. Failure of the heat-shock protein 70 locus to cosegregate with blood pressure in spontaneously hypertensive rat $\mathrm{x}$ Wistar-Kyoto rat cross. J Hypertens 1993; 11: 1047-1051

79 Hamet P, Malo D, Hashimoto T, Tremblay J. Heat stress genes in hypertension. J Hypertens Supp/ 1990; 8: S47-S52.

80 Kaufmann SHE. Heat shock proteins and the immune response. Immunol Today 1990; 11: 129-136.

81 Young RA. Stress proteins and immunology. Annu Rev Immunol 1990; 8: 401-420.

82 Ishizaka N, Aizawa T, Ohno M, Usui Si S, Mori I, Tang SS, Ingelfinger JR, Kimura S, Nagai R. Regulation and localization of HSP70 and HSP25 in the kidney of rats undergoing long-term administration of angiotensin II. Hypertension 2002; 39: 122-128.

83 Bravo J, Quiroz Y, Pons H, Parra G, Herrera-Acosta J, Johnson RJ, Rodríguez-Iturbe B. Vimentin and heat shock protein expression are induced in the kidney by angiotensin and by nitric oxide inhibition. Kidney Int 2003; 64(Suppl 86): S46-S51. 
84 Pockley AG, De Faire U, Kiessling R, Lemne C, Thulin T, Frostegård J. Circulating heat shock protein and heat shock protein antibody levels in established hypertension. J Hypertens 2002; 20: 1815-1820.

85 Pockley AG, Georgiades A, Thulin T, de Faire U, Frostegard J. Serum heat shock protein 70 levels predict the development of atherosclerosis in subjects with established hypertension. Hypertension 2003; 42: 235-238.

86 Parra G, Quiroz Y, Salazar J, Bravo Y, Pons H, Chavez M, Johnson RJ, Rodriguez-Iturbe B. Experimental induction of salt-sensitive hypertension is associated

with Iymphocyte proliferative response to HSP70. Kidney Int Supp/ 2008; 111: S55-S59.

87 Romero F, Yaguas K, Quiroz Y, Johnson RJ, Rodríguez-Iturbe B. Spontaneously hypertensive rats (SHR) develop renal heat shock protein 70 (HSP70) expression and serum anti-HSP70 antibodies (abstract). World Congress of Nephrology; 21-25 April 2007; Rio de Janeiro, Brazil (M-PO-0684). Proceedings of WCN 2007, p 246. 